\title{
ӨЛЗИЙТ НУУРЫН ЭМЧИЛГЭЭНИЙ ШАВРЫН УУСМАЛ, ТУУНИЙ БАКТЕРИЙН ЭСРЭГ ҮЙЛЧЛЭЛИЙН ДҮНГЭЭС
}

\author{
Г.Долмаа ${ }^{1}$, Г.Ганзаяа ${ }^{1}$, Ч.Эрхэмцэцэг \\ О.Мөнхтуяа ${ }^{3}$, Б.Уянга ${ }^{2}$, Б.Очирбат ${ }^{2}$, С.Наранцэзฺэ ${ }^{4}$ \\ I- ШУА-ийн Хими, хими технологийн хүрээлэн ganzaya g@yahoo.com \\ 2. “Ач” АУДэС, микробиологийн тэнхим

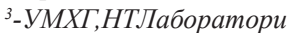 \\ ${ }^{4}-$ БГД ЭМН
}

\section{Abstract}

The mud solution was isolated from mud in Ulziit lake and have been determined their chemical composition. Mud solution was obtained by pressing method, water soluble by extracting with water.

Yield of solution (in natural mud) was $18.1 \%$, yield of water extract was $17.05 \%$, dry residue in mud solution and water extract were $18.37 \%$ and $17.96 \%$, respectively.

In mud solution were anions with following concentration: $\mathrm{Cl}^{-}(52895 \mathrm{mg} / \mathrm{l}), \mathrm{SO}_{4}^{2-}(2650$ $\mathrm{mg} / \mathrm{l}), \mathrm{NO}_{2}^{-}(11.2 \mathrm{mg} / \mathrm{l}), \mathrm{NO}_{3}^{-}(0.0 \mathrm{mg} / \mathrm{l}), \mathrm{HCO}_{3}^{-}(1830 \mathrm{mg} / \mathrm{l})$, kations with following concentration: $\mathrm{NH}_{4}^{+-}(2.4 \mathrm{mg} / \mathrm{l}), \mathrm{Fe}^{3+-}(0.0 \mathrm{mg} / \mathrm{l}), \mathrm{Fe}^{2+-}(0.0 \mathrm{mg} / \mathrm{ll})$; in water extract were anions with following concentration: $\mathrm{Cl}^{-}(36476 \mathrm{mg} / \mathrm{l}), \mathrm{SO}_{4}^{2-}(2100 \mathrm{mg} / \mathrm{l}), \mathrm{NO}_{2}^{-}(0.0 \mathrm{mg} / \mathrm{l}), \mathrm{NO}_{3}^{-}(0.0 \mathrm{mg} / \mathrm{l}), \mathrm{HCO}_{3}^{-}(1982.5$ $\mathrm{mg} / \mathrm{l})$ kations with following concentration: $\mathrm{Ca}^{2+}(400.8 \mathrm{mg} / \mathrm{l}), \mathrm{Mg}^{2+}(8208 \mathrm{mg} / \mathrm{l}), \mathrm{NH}_{4}^{+-}(2.1 \mathrm{mg} / \mathrm{l})$ , $\mathrm{Fe}^{3+-}(0.0 \mathrm{mg} / \mathrm{l}), \mathrm{Fe}^{2+-}(0.0 \mathrm{mg} / \mathrm{l})$. The content of macro and microelements in mud solution was $0.0003->3 \%$.

The mud solution of Ulziit lake was extracted by chloroform and investigated by chromatomass-spectral method. This analysis shows that mud solution contains hydrocarbons $14.87 \%$, dialkylphtalates $48.15 \%$, organic acids $36.97 \%$, respectively.

\section{Хураангуй}

Өлзийт нуурын эмчилгээний шаврын уусмалыг ялгаж химийн найрлагыг нь тогтоов. Шаврын уусмалыг шахах аргаар, усанд уусдаг хэсгийг нь усаар хандлан ялгав. Уусмалын гарц $18,1 \%$ /байгалийн шаварт/, усан хандын гарц 17,05\%, шаврын уусмал болон усан хандын хуурай үлдэгдэл $18,37 \%$ ба $17,96 \%$ тус тус байв. Шаврын уусмалд $\mathrm{Cl}^{-}, \mathrm{SO}_{4}^{2-}, \mathrm{NO}_{2}^{-}$, $\mathrm{NO}_{3}^{-}, \mathrm{HCO}_{3}^{-}$(харгалзаагаар 52895; 2650; 11.2; $1830 \mathrm{Mг} /$ ) анион, $\mathrm{NH}_{4}^{+}, \mathrm{Fe}^{3+}, \mathrm{Fe}^{2+}$ (харгалзаагаар 2,$4 ; 0.0 ; 0.0$ мг/л) катион, усан хандад $\mathrm{Cl}^{-}, \mathrm{SO}_{4}{ }^{2-}, \mathrm{NO}_{2}{ }^{-}, \mathrm{NO}_{3}^{-}, \mathrm{HCO}_{3}^{-}$(харгалзаагаар 36476; 2100 ; $0.0 ; 0.0 ; 1982.5$ мг/л) анион, $\mathrm{Ca}^{2+}, \mathrm{Mg}^{2+}, \mathrm{NH}_{4}^{+}, \mathrm{Fe}^{3+}, \mathrm{Fe}^{2+}$ (харгалзаагаар 400,8; $8208 ; 2,1 ; 0.0$; 0.0 мг/л ) катион агуулагдаж байна. Макро, микро элементүүдийн хувьд $\mathrm{Si}, \mathrm{Al}, \mathrm{Fe}, \mathrm{Ca}, \mathrm{Mg}$, $\mathrm{Na}, \mathrm{Cr}, \mathrm{Ni}, \mathrm{V}, \mathrm{Cu}, \mathrm{Pb}, \mathrm{Zn}, \mathrm{P}$, зэрэг элементүүд 0.0003- >3 \% агуулгатай байна. Өлзийт нуурын шаврын уусмалыг хлороформоор хандлаж хлороформын хандыг хромато-масс-спектрийн аргаар судлахад нүүрсустөрөгчид (октадекан $/ \mathrm{C}_{18} \mathrm{H}_{38} /$, эйкозан $/ \mathrm{C}_{20} \mathrm{H}_{42} /$, генейкозан $/ \mathrm{C}_{21} \mathrm{H}_{44} /$, докозан $/ \mathrm{C}_{22} \mathrm{H}_{46} /$, тетракозан $/ \mathrm{C}_{24} \mathrm{H}_{50}$, гексакозан $/ \mathrm{C}_{26} \mathrm{H}_{54} /$, гептакозан $\left./ \mathrm{C}_{27} \mathrm{H}_{56} /\right) \quad 14,87 \%$, фталатууд $48,15 \%$, хүчлүүд $36,97 \%$ тус тус агуулагдаж байгаa нь тогтоогдлоо. 


\section{Оршил}

Эмчилгээний шаврын комплекс үйлчлэлийн механизмд түүний физик химийн шинж чанар тодорхой үүрэгтэй байдаг [1]. Эмчилгээний шаварт олон төрлийн биологийн идэвхит бодис агуулагддаг бөгөөд эдгээрийн тодорхой хэсэг нь усан хандад орж ирдэг. Иймээс эмчилгээний шаврын шингэн фаз буюу шаврын уусмалын организмд үйлчлэх процесс судлаачдын анхаарлыг зүй ёсоор татдаг. Оросын судлаачид судалгааныхаа үр дүнд шаврын уусмалыг биогенны стимулятор гэж нэрлэсэн нь зүй ёсны асуудал юм [2, 3].

Монгол оронд эмчилгээний шавар бүхий нуурууд нилээд байдгийн дотор Өлзийт нуурын эмчилгээний шаврыг эрт дээр үеэс ард түмэн элдэв өвчинд хэрэглэсээр ирсэн хэдий ч одоог хүртэл түүний найрлага, шинж чанар эмчилгээний үйлчлэлийг нь тогтоосон судалгааны ажил төдийлөн байхгүй билээ. Энэ нуурын ус нь $\mathrm{NaCl}, \mathrm{MgSO}_{4}$, хужир бүхий сульфатын төрлийн давслаг нуур хэмээн судлаачид тогтоосон байдгийг үндэслэн шаврын уусмалыг нь нарийвчлан судлах нь зайлшгүй шаардлагатай юм [4].

Түлхүүр үг: шаврын уусмал, хандлагдах бодис, биологийн идэвхит бодис, нянгийн эсрэг үйлчилгээ

\section{Зорилго}

Шаврын эмчилгээний чухал ач холбогдолтой бэлдмэлүүдийн нэг хэсэг нь хандлагдах бодис байдаг тул энэ аулын зорилго нь Өлзийт нуурын эмчилгээний шаврын уусмалыг ялгах, улмаар химийн найрлага шинж чанарыг нь тогтоон биологийн идэвхийг нь судлахад оршино.

\section{Судалгааны арга зүй}

Өлзийт нуур нь Төв аймгийн нутагт Зуунмод хотоос баруун урагш 87 км-т, далайн төвшинээс дээш 1320 м-т, газарзүйн өргөргийн 46058', уртрагийн 106 50 ' солиболцолд орших эрдэс ихтэй, зуйван хэлбэртэй зүүн хойноосоо баруун урагш сунаж тогтсон нуур болно. Энэхүу судалгаанд ашигласан шаврын дээжийг 2006 онд MNS 5848:2008 [6] стандартын дагуу авсан.

Шаврын уусмалыг прессээр шахаж гарган авав [5]. Шаврын уусмалын анион, катионы агууламжийг ион солилцооны хроматографын болон химийн аргаар; макро, микро элементүүдийг атомын цацруулалтын спектрийн хагас тоон шинжилгээний аргаар ДФС-8 600шт/мм багажаар, органик бодисын бүрэлдэхүүнийг хроматомасс-спектрометр LKB2091 ба HP5971A багаж дээр BD-58 SE-54 дүүргэгч бүхий 50м урттай хялгасан колонк ашиглан 4град/мин программчилалтайгаар тус тус гүйцэтгэв. Шаврын уусмалын биологийн идэвхийг ялган авсан болон батлагдсан өсгөвөрүүдийн өсөлтөд нөлөөлөх байдал, нянг үхүүлэх чадвартай эсэхийг уламжлалт аргуудаар ашиглан тогтоов.

БИЧ 1 болон БИЧ 2 бэлдмэлийн 0,$5 ; 1,0 ; 1,5 ; 2,0 ; 2,5 ; 3,0 ; 3,5 ; 4,0 ; 6,0 ; 8,0$ \%-ын концентрацитай уусмалуудын нян үхүүлэх идэвхийг тодорхойлох шинжилгээг Staph. Aureus /ATTC 29213 /, Str. faccalis, E.coli / NCD 02328 /, Salm. Serro / NCTC 5801 / - ын өсгөвөрүүд дээр явуулав. Судалгааг гүйцэтгэхдээ MNS4891:1999, MNS4835:1999, MNS4834:1999 [6] задлан шинжилгээний аргын стандартуудыг ашиглав. Туршилтыг явуулахдаa Mac Farland -ын стандарт уусмалуудтай харьцуулан 1- р хуруу шилэнд нянгийн булинга бэлдсэн, үүнээсээ 1 мл-ыг авч тус бүр нь 9 мл физиологийн уусмал (0,85\% NaCl-ын уусмал, pH 6,5 
) бүхий 4 хуруу шилэнд $10^{5}, 10^{4}, 10^{3}, 10^{2}$ хүртэл аравтын дарааллаар шингэрүүлж, сүүлийн хуруу шилнээс 1 мл уусмал асгах замаар щингэрүүлэлт хийв. Staph. aureus, Str. Faecalis - ыг цустай тэжээлт орчинд, E.coli - г EMB агарт, Salm. Serro - г SS агарт өсгөвөр тус бүрээс сонгомол орчинд тарьж халуун тогтоогуурын $37^{\circ} \mathrm{C}-\mathrm{T} 18-24$ цаг өсгөвөрлөн цэвэр колоноо ургуулав. Шингэрүүлэлт бүр дээр ариун дусаагуураар БИЧ 1, БИЧ 2 - ын 0,5-8\% -ын уусмалаас хуруу шилтэй уусмал тус бүрд 1 мл дусаан, тасалгааны хэмд 1 цаг байлгав. Дараа нь нянгийн булингатай шингэрүүлэлт бүхий хуруу шил тус бүрээс сонгомол тэжээлт орчинд тарилт хийж, халуун тогтоогуурын 37 градуст өсгөвөрлөн ургалтыг ажиглан, үр дүнг уншив.

\section{Судалгааны ажлын үр дүн}

Стандартын дагуу Өлзийт нуураас авсан дээжнээс шаврын уусмалыг ялгахад гарц $18,1 \%$, уусмалын хуурай үлдэгдэл 18,37\%, урвалын орчин $\mathrm{pH} 8,31$, хувийн жин 1,291г/ $\mathrm{cm}^{3}$; уусмалыг ялгасаны дараах шаврын усан хандын гарц 17,05\%, хуурай үлдэгдэл $17,96 \%$, урвалын орчин рН 8,22 байна.

\section{1-р хүснэгт. Өлзийт нуурын шаврын уусмал болон усан хандын найрлага}

\begin{tabular}{|c|c|c|}
\hline Үзуүлэлт & Өлзийт (шаврын уусмал) & Өлзийт (усан ханд) \\
\hline $\mathrm{pH}$ & 8.31 & 8.22 \\
\hline (Cond), $\mu \mathrm{S} / \mathrm{sm}$ & 149000 & - \\
\hline (TDS), ppm & 69300 & - \\
\hline $\mathrm{CI}^{-}, \mathrm{мг} / л$ & 52895 & 36476.25 \\
\hline $\mathrm{SO}_{4}^{2-}$, мГ/л & 2650 & 2100 \\
\hline $\mathrm{NO}_{2}^{-}, \mathrm{мг} / л$ & 11.2 & - \\
\hline $\mathrm{HCO}_{3}^{-}, \mathrm{мг} / л$ & 1830 & 1982.5 \\
\hline $\mathrm{Ca}^{2+}, \mathrm{M \Gamma} / \mathrm{л}$ & 1600 & 400.8 \\
\hline $\mathrm{Mg}^{2+}, \mathrm{M \Gamma} /$ л & 28728 & 8208.0 \\
\hline $\mathrm{NH}_{4}^{+}$, Мг/л & 2.4 & 2.1 \\
\hline
\end{tabular}

Өлзийт нуурын шаврын уусмал дахь $\mathrm{Ca}^{2+}, \mathrm{Mg}^{2+}$ ионы концентрацыг ион хроматограф, усан хандынхыг химийн аргаар тус тус тодорхойлов. Харин шаврын уусмал болон усан ханд дахь бусад ионы найрлагыг химийн аргаар тодорхойлсон болно (хүснэгт 1). Хүснэгт 1-ээс харахад шаврын уусмалд $\mathrm{Cl}^{-}, \mathrm{SO}_{4}^{2-}, \mathrm{NO}_{2}^{-}, \mathrm{NO}_{3}^{-}, \mathrm{HCO}_{3}^{-}$анион (харгалзаагаар 52895; $2650 ; 11.2 ; 0.0 ; 1830$ мг/л), $\mathrm{NH}^{4+}, \mathrm{Fe}^{3+}, \mathrm{Fe}^{2+}$ катион (харгалзаагаар 2,4; $0.0 ; 0.0$ мг/л) усан хандад $\mathrm{Cl}^{-}, \mathrm{SO}_{4}^{2-}, \mathrm{NO}_{2}^{-}, \mathrm{NO}_{3}^{-}, \mathrm{HCO}_{3}^{-}$анион (харгалзаагаар 36476,$25 ; 2100 ; 0.0 ; 0.0 ; 1982.5$ мг/л), $\mathrm{Ca}^{2+}, \mathrm{Mg}^{2+}, \mathrm{NH}^{4+}, \mathrm{Fe}^{3+}, \mathrm{Fe}^{2+}$ катион (харгалзаагаар 400.8; 8208.0; 2.1;0.0; 0.0 мг/л ) агуулагдаж байна. Шаврын уусмалын цахилгаан дамжуулах чанар (Cond) $149000 \mu \mathrm{S} / \mathrm{sm}$, шаврын уусмалд ууссан нийт давсны хэмжээ (TDS) 69300 ppm байв (Хүснэгт 1).

Шаврын уусмалын элементийн найрлагыг атомын цацруулалтын спектрийн хагас тоон шинжилгээгээр ДФС-8 600 шт/мм багажийн тусламжтай тодорхойлоход $\mathrm{Si}, \mathrm{Al}, \mathrm{Fe}$, $\mathrm{Ca}, \mathrm{Mg}, \mathrm{Na}, \mathrm{Cr}, \mathrm{Ni}, \mathrm{V}, \mathrm{Cu}, \mathrm{Pb}, \mathrm{Zn}, \mathrm{P}$, зэрэг макро, микро элементүүд $0.0003->3$ \% агуулгатай байна.

Өлзийт нуурын шаврын уусмалын хлороформын хандад нийт 19 пик илэрсний дотор нүүрсустөрөгчид (октадекан, эйкозан, генейкозан, докозан, тетракозан, гексакозан, гептакозан) 14,87\%, диалкилфталатууд (диэтилфталат, диизобутилфталат, дибутилфталат) 48,15\%, органик хүчлүүд (тетрадеканы хүчил, палмитины хүчил, олейны хүчил, стеарины 
хүчил) $36,97 \%$ агуулагдаж байна. Хлороформд уусдаг нэгдлийн дотор байгаа органик нэгдлүүдэд диалкилфталатуудаас гадна органик хүчлийн нийлмэл эфирүүд ажиглагдахгүй байгаа нь бусад нуурын органик нэгдлийн бүрэлдэхүүнээс нилээд ялгаатай болно.

БИЧ 1, БИЧ 2 -ын 0,5-8\%-ын уусмалуудад нян үхүүлэх болон нянгийн өсөлт зогсоох үйлчилгээг судлан үзэхэд эдгээр уусмалууд нь Staph. Aureus /ATTC 29213 / -д, Str. Faecalis-д 1 мл-т $10^{6}-10^{2}$-д бүгдэд нь нянгийн ургалттай, бактерийн эсрэг нөлөөлөл байхгүй байна. БИЧ 1, БИЧ 2 -ын 0,5-8\%-ын уусмал нь E.coli / NCD 02328 /, Salm. Serro / NCTC 5801 / -д $10^{6}-10^{3}$-д нянгийн эсрэг нөлөөлөл байхгүй , харин $10^{2}-$ д нөлөөлөл дунд зэрэг болох нь тогтоогдов. (Хүснэгт 2,3).

\section{2- р хүснэгт. БИЧ 1, БИЧ 2 -ын 0,5-8\%-ын уусмалуудын нян ҮхҮүлэх болон нянгийн өсөлт зогсоох үйлчилгээ}

\begin{tabular}{|c|c|c|c|c|c|c|c|c|c|c|c|c|c|c|c|c|c|}
\hline \multirow{3}{*}{ Д/д } & \multirow{3}{*}{$\%$} & \multicolumn{8}{|c|}{ Staph. aureus } & \multicolumn{8}{|c|}{ Str. faecalis } \\
\hline & & \multicolumn{4}{|c|}{ БИЧ 1} & \multicolumn{4}{|c|}{ БИЧ 2} & \multicolumn{4}{|c|}{ БИЧ 1} & \multicolumn{4}{|c|}{ БИЧ 2} \\
\hline & & $10^{5}$ & $10^{4}$ & $10^{3}$ & $10^{2}$ & $10^{5}$ & $10^{4}$ & $10^{3}$ & $10^{2}$ & $10^{5}$ & $10^{4}$ & $10^{3}$ & $10^{2}$ & $10^{5}$ & $10^{4}$ & $10^{3}$ & $10^{2}$ \\
\hline 1 & 0,5 & + & + & + & + & + & + & + & + & + & + & + & + & + & + & + & + \\
\hline 2 & 1,0 & + & + & + & $<10$ & + & + & + & + & + & + & + & - & + & + & + & + \\
\hline 3 & 1,5 & + & + & + & + & + & + & + & + & + & + & + & - & + & + & + & + \\
\hline 4 & 2,0 & + & + & + & - & + & + & + & - & + & + & + & + & + & + & + & - \\
\hline 5 & 2,5 & + & + & + & - & + & + & + & - & + & + & + & - & + & + & + & - \\
\hline 6 & 3,0 & + & + & + & - & + & + & + & - & + & + & + & - & + & + & + & - \\
\hline 7 & 3,5 & + & + & + & - & + & + & $<10$ & - & + & + & + & - & + & + & + & - \\
\hline 8 & 4,0 & + & + & + & - & + & + & $<10$ & - & + & + & + & - & + & + & - & - \\
\hline 9 & 6,0 & + & + & + & + & + & + & + & + & + & + & + & + & + & + & + & + \\
\hline 10 & 8,0 & + & + & + & $<10$ & + & + & . & $<10$ & + & + & + & + & + & + & + & + \\
\hline
\end{tabular}

\section{3-р хүснэгт. БИЧ 1, БИЧ 2 -ын 0,5-8\%-ын уусмалуудын нян үхүҮлэх болон нянгийн өсөлт зогсоох үйлчилгээ}

\begin{tabular}{|c|c|c|c|c|c|c|c|c|c|c|c|c|c|c|c|c|c|}
\hline \multirow{3}{*}{ Д/д } & \multirow{3}{*}{$\%$} & \multicolumn{8}{|c|}{ E. Coli } & \multicolumn{8}{|c|}{ Salm. serro } \\
\hline & & \multicolumn{4}{|c|}{ БИЧ 1} & \multicolumn{4}{|c|}{ БИЧ 2} & \multicolumn{4}{|c|}{ БИЧ 1} & \multicolumn{4}{|c|}{ БИЧ 2} \\
\hline & & $10^{5}$ & $10^{4}$ & $10^{3}$ & $10^{2}$ & $10^{5}$ & $10^{4}$ & $10^{3}$ & $10^{2}$ & $10^{5}$ & $10^{4}$ & $10^{3}$ & $10^{2}$ & $10^{5}$ & $10^{4}$ & $10^{3}$ & $10^{2}$ \\
\hline 1 & 0,5 & + & + & + & $<10$ & + & + & $<10$ & $<10$ & + & + & + & + & + & + & + & + \\
\hline 2 & 1,0 & + & + & + & $<10$ & + & + & $<10$ & + & + & + & + & + & + & + & + & + \\
\hline 3 & 1,5 & + & + & + & $<10$ & + & + & + & + & + & + & + & + & + & + & + & + \\
\hline 4 & 2,0 & + & + & . & - & + & + & + & - & + & + & + & + & + & + & + & + \\
\hline 5 & 2,5 & + & + & . & - & + & + & + & - & + & + & + & + & + & + & + & + \\
\hline 6 & 3,0 & + & + & . & $<20$ & + & + & + & - & + & + & + & - & + & + & + & - \\
\hline 7 & 3,5 & + & + & . & $<10$ & + & + & + & $<10$ & + & + & + & - & + & + & + & - \\
\hline 8 & 4,0 & + & + &. & $<20$ & + & + & $<10$ & - & + & + & + & - & + & + & + & - \\
\hline 9 & 6,0 & + & + & + & $<10$ & + & + & + & + & + & + & + & + & + & + & + & + \\
\hline 10 & 8,0 & + & + & + & + & + & + & . & + & + & + & + & - & + & + & + & - \\
\hline
\end{tabular}

/-/- нянгийн ургалтгүй 


\section{Дүгнэлт}

1. Өлзийт нуурын шаврын уусмалын гарц $18,1 \%$ (байгалийн шаварт), усан хандын гарц 17,05\%, шаврын уусмал болон хандын хуурай үлдэгдэл харгалзаагаар 18,37\% ; $17.96 \%$ байна. Шаврын уусмалд болон усан хандад $\mathrm{Cl}^{-}, \mathrm{SO}_{4}^{2-}, \mathrm{NO}_{2}^{-}, \mathrm{HCO}_{3}^{-}$анион, $\mathrm{Ca}^{2+}$, $\mathrm{Mg}^{2+}, \mathrm{NH}^{4+}$, катион өндөр агуулгатай байгааг тогтоов. Шаврын уусмалын цахилгаан дамжуулах чанар (Cond) $149000 \mu \mathrm{S} / \mathrm{sm}$, шаврын уусмалд ууссан нийт давсны хэмжээ (TDS) 69300 ppm байв.

2. Шаврын уусмалын органик бодист нүүрсустөрөгчид $14,87 \%$, диалкилфталатууд $48,15 \%$, органик хүчлүүд $36,97 \%$ агуулагдаж байна.

3. БИЧ 1, БИЧ 2-ын 0,5-8\%-ын уусмал нь Staph. Aureus, Str. Faecalis, E.coli, Salm. Serro зэрэг нянгуудад $10^{6}-10^{3}$ дахин шингэрүүлсэн үед нянгийн эсрэг нөлөөлөл байхгүй, харин грам эерэг нянд $10^{2}$, грам сөрөг савханцарт $10^{3}-10^{2}$ дахин шингэрүүлсэн үед нянгийн өсөлт болон биологийн идэвх бууруулдаг болох нь тогтоогдож байна.

\section{Ном зүй}

1. Е.Ф. Левицкий, Д.И. Кузменько, Б.И. Лаптев Комплексное применение природных лечебных факторов и поля постоянных магнитов в эксперименте и клинике. Изд. Томского Унив-та, 2001, с 154

2. Н.А.Дербенцева, В.А.Фрадкин “Исследование химического состава и антибактериалных свойств паровых дестиллатов и водных экстрактов Хаапсулской лечебной грязи”.

Известия Академии Наук Эстонской ССР. ТОМ V. Серия Биологическая, 1956, №2, с.176181

3. Г.Долмаа, Ц. Ариунтунгалаг “Эмчилгээний шавар”, УБ, 2002 он

4. Б.Намбар “Эмчилгээний шаврын ид шид”, УБ, 2006 он

5. Бахман В.И, Овсяникова К.А. “Методика лечебной грязей” 1960, изд. с. 53

6. Монгол улсын стандарт: MNS5848:2008, MNS4891:1999, MNS4835:1999, MNS 4834:1999 